\title{
AN ANALYSIS ON COMPENSATION OF CLAIMS REGARDING TO PERSONAL INJURY AND LOSS OF EARNING ON SEVERAL COURT CASES
}

\author{
N. Awang ${ }^{1, *}$, N. Majid ${ }^{2}$, S. Saleh ${ }^{1}$ and J. Said ${ }^{1}$ \\ ${ }^{1}$ Faculty of Computer and Mathematical Sciences,UniversitiTeknologi MARA, Tapah, Perak, \\ Malaysia \\ ${ }^{2}$ School of Mathematical Sciences, Faculty of Science and Technology, UniversitiKebangsaan \\ Malaysia, Bangi, Selangor, Malaysia
}

Published online: 10 November 2017

\begin{abstract}
Road accident is a major contributor in personal injury cases. The plaintiff or accident victims are entitled to compensation from injuries. This study aims to analyse the amount of damages received compared to the amount of damages in personal injury guideline from Completion of the Review of the Compendium of Personal Injury Award. A comparison between the system multiplier set forth in Section 28A of the Civil Law Act (Amendment) Act 1984 will be carried out with Odgen Table from United Kingdom customised with the Expected Life Tables of Malaysians. A total of 30 court cases from 1989 to 2013 are analysed in this study which includes all accidents on the road. The results showed that there were two cases of injury beyond the maximum range of the guidelines which are scars and eye injuries. Therefore, it is suggested that we should look at multiplier which is fairer in dealing with loss of earnings.
\end{abstract}

Keywords: quantum; loss of earnings; multiplier.

Author Correspondence, e-mail: najihanali@uitm.edu.my

doi: http://dx.doi.org/10.4314/jfas.v9i6s.28 


\section{INTRODUCTION}

Road accident cases involving various types of vehicles are not exactly strangers in Malaysia. Almost every day there are reports of cases of road accidents. According to [1], Malaysia is ranked among the most dangerous and the development of the country as a main factor. A study conducted by the University of Michigan Transportation Research Institute shows that Malaysia is among the top 25 most dangerous for motorists with a record of 30 deaths per 100,000 populations [1].

Besides Malaysia, Thailand is listed as 25 most dangerous countryamong Southeast Asian countries with 44 deaths for every 100,000 populations. The string of accidents in Malaysia raise also a big impact on the Malaysian economy suffered losses of up to RM9 billion in 2009 [2].

The increases of road accidents also have an impact on personal injury claims from motor accidents. In Malaysia, there is no specific or scientific method assigned by the judge in calculating the award of compensation in personal injury and loss of earnings. Basically, both parties have to submit evidence and medical reports mainly in the pain and suffering claims under personal injury [3-4].

Law of personal injury also known as tort law [5]. Tort law involves the study of wrongful conduct consists by one party, claimant who has been wronged and the second party who have done wrong known as defendant or referred as tortfeasor [6].

This law provides the claimant with legal rights and remedies that may be enforced in a court of law. Tort laws seeks to achieve several goals. It serves to protect innocent persons and their property from the careless or intentional injury of tortfeasors. This would render the tortfeasors responsible for their misconduct. Besides, tort law encourages minimum standards in avoiding public from injuring others through heedless, reckless or intentional behaviour [6]. This encourage the claimant to get their compensation according to their injury [7].

Cases involving personal injury in Malaysia are governed under the Civil Law Act 1956. Section 3(1) of the Act states that English common law should be applied in the absence of local legislations and suitable with local circumstances in Malaysia. For personal injury cases with no deaths, there is no available specific legislation. Hence, English common law prevails as the 
governing law. However, matters relating to certain aspects of the law of damages due to injury are covered in the amendment of the Civil Law Act 1956 [8].

This study examines the guidelines addressing the amount of personal injury from Completion of the Review of the Compendium of Personal Injury Award which was introduced in 2010. The guidelines is applied for analysing the appropriate awards to be made in respect of the different types of injuries suffered by a claimant in a personal injury suit or claim.

Under each injury, a range of figures is tabulated based on the contemporary trend of awards in Malaysian courts and should be adapted to suit the particular type and nature of an injury. It is noteworthy that hardly any two injuries are ever identical in nature and more so the individuals suffering them.

This guidelines details out orthopedics injuries from top to toe, literally, internal injuries affecting the organs including the brain. An overlap of injuries, both external and internal may inevitably occur in which case an element of overlapping will have to be taken into account [9].

\subsection{Compensation in Personal Injury}

Compensation is the amount of compensation ordered by the judge or court against a defendant who has pleaded responsible or held liable for the offenses committed and requires some amount of payment to a plaintiff [8]. According to [10], general damages for personal injury are evaluated under four main sections. The first section is pain and suffering and loss of amenities. Second section relates to loss of future earnings. The third one is lost revenue and damages capacity, and lastly the future care costs. The evaluation of personal injury is done by reference to a predetermined multiplier Section 28A of the Civil Law (Amendment) Act 1984. However, the accuracy of the multiplier has been disputed. It renders that there is no specific method to assign the award of economic damages especially in personal injury and wrongful death. The lawyers will do the evaluation based on the interpretation of the judges in previous cases of laws. As a result, there is no standard method employed by the lawyers in evaluating the personal injury claims in Malaysia [3]. 


\subsection{Multiplier-Multiplicand Approach}

The loss of future earnings is calculated by multiplying the multiplier (the annual loss of future earnings) with multiplicand (the number of years from the trial date until the year that person ispredicted to separate from workforce). Thus, the calculation for the loss of future earnings is:

Multiplier=Pre-accident Earning- Post-accident Earning

Multiplicand= Retirement Age- Age at Trial Date

Second approach adopted by [3] uses a series of actuarial tables known as the Odgen Table that would help the courts to assess the size of awards to be made to personal injury and fatal accident case.

\section{METHODOLOGY}

The calculation the loss of future earnings involves the use of the multiplier. According to [11], the calculation for compensation of future earnings is as follows.

Multiplicand $\mathrm{x}$ Multiplier $=$ Present Capital Value

The first step is to determine the multiplicand by calculate the present value of the future loss or expenses (or if an ongoing recurrent loss, the present day annual loss or expense). Next, the "multiplier" found in the relevant table will be used to produce the present capital value of the future loss multiplies the multiplicand.

\subsection{Introduction to the Odgen Table}

In attempt to bring Actuarial principles to the use of multiplier, the Government Actuary's Department, United Kingdom (GAD) introduced a set of multipliers in 1984 known as "Actuarial Tables with Explanatory Notes for Use in Personal Injury and Fatal Accident Cases" which also known as Odgen Table". Sir Michael Odgen developed the Odgen Table. The Table was first published in 1984 and has been continuously updated since then. The latest edition is $6^{\text {th }}$ edition published in 2007 [3].

The Odgen Tables are designed to assist those concerned with calculating lump sum damages for future losses in personal injury and fatal accident cases in the United Kingdom. According to this table, the plaintiff who is the victims assumed would like to invest the award in index-linked gilts. Gilts are defined as risk-free vehicle producing an income in accordance with the fluctuations of the Retail Price Index. The objective of the Odgen Table serves as a 
specific guidance to the courts and judges in England and Wales to determine the economic losses suffered by plaintiff [12].

The Table, the lawyers or judges will find the appropriate figure for the present value of a particular loss or expense. The user must first choose the relevant table relating to the period of loss or expense for which the individual claimant is to be compensated and to the gender of the claimant or where appropriate, the claimant's defendants.

\subsection{Human Life Contingencies Model}

The life contingencies of a person will affect the multiplier. In [13] describes the general equation for calculating life contingencies model in the Odgen Table:

$$
L=A_{x} \sum v^{t}{ }_{t} p_{x}
$$

where $L=$ the amount of loss of future earnings, $A_{x}=$ the amount of earnings monthly, $\mathrm{v}^{\mathrm{t}}=$ discount factor, $\mathrm{p}_{\mathrm{x}}=$ probability human life survive at age $\mathrm{x}$, and at years $\mathrm{t}, \mathrm{t}=$ yearsand

$$
\text { Multiplier }=\sum v^{t}{ }_{t} p_{x}
$$

$$
v^{t}=(1+i)^{-1}
$$

\section{RESULTS AND DISCUSSION}

Evaluation of personal injury involving traffic accident from a published law report was collected from the online law database, Lexis Legal Research for Academics [14]. The cases analysed were obtained from the Malayan Law Journal. A total of 30 case laws decisions have been recorded as the main material for analysis starting from 1989 until 2013.

\subsection{Number of Cases in Each Personal Injury}

Fig. 1 explains the number of cases involved in each component of personal injury. There are six major types of injury relevant to personal injury claims including prosthetic leg, injuries to the lower limbs, upper limbs injuries, head injuries, spinal injuries and other minor injuries. An injury in the lower limbs consists of the anatomy of ankle, leg, knee, thigh and whole leg. While injury to upper limbs includes the anatomy of arm, forearm, clavicle and shoulder, humerus, radius and ulna, hand, fingers and metacarpals. Head injury involves the anatomy of the brain and skull, eyes and vision, zygoma and the teeth. An injury in the spine represents the anatomy of the spine, internal organs, pelvis and quadriplegia (serious injury). Minor injury consists of injury scars and lacerations. 
Fig. 1 represents the types of recorded during the period of study. Injuries relating the upper limbs recorded the highest cases with 12 cases, followed by injuries to the lower limbs with nine cases. The third highest is minor injuries and head injuries with eight cases. This is further followed by the injuries to the spine and the others injuries with five cases. The smallest cases come from the claims of prosthesis with only two cases.

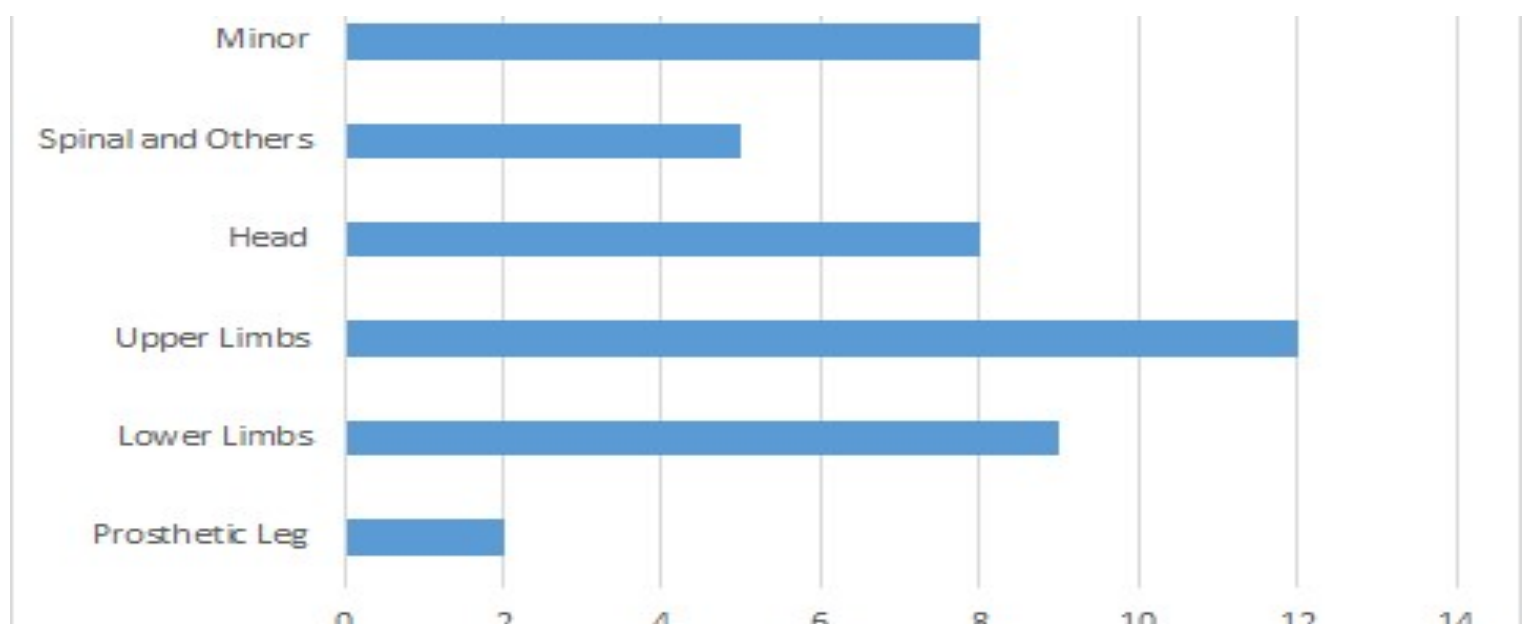

Fig.1. Number of cases in each personal injury

\subsection{The Amount of Damages Received by the Respondent or Plaintiff}

Table 1 represents the amount of damages received by the respondent or plaintiff evaluated using the guidelines from Compendium of Personal Injury Awards. There are five categories of the amount of damages.

Table 1. Categories amount of damages

\begin{tabular}{|c|c|}
\hline Categories Amount of Damages & Definition \\
\hline Minimum range & $\begin{array}{l}\text { Amount of damages in the minimum range of the } \\
\text { guidelines }\end{array}$ \\
\hline Maximum range & Amount of damages at the maximum level \\
\hline Beyond the range & $\begin{array}{l}\text { Amount outside the maximum range and } \\
\text { minimum. }\end{array}$ \\
\hline In the range & $\begin{array}{l}\text { Amount of damages in the range minimum and } \\
\text { maximum }\end{array}$ \\
\hline Others & Not decided exclusively by a court \\
\hline
\end{tabular}

Fig. 2 shows five greatest amount of compensation received by the respondents or plaintiffs. A total of 45 cases of injuries that represented all 30 court cases in traffic accidents. Based on 
the figure, the level of compensation amount outside of the range recorded the highest number of 15 cases of injury (33.33\%). The second record is the amount for the other injuries 13 cases $(28.89 \%)$. Next, the amount of damages in the range of eight cases of injuries $(17.78 \%)$ followed by the maximum range with six cases of injuries $(13.33 \%)$. The minimum range has the least cases with only three cases of injuries only (6.67\%) of the 45 cases involved injuries.

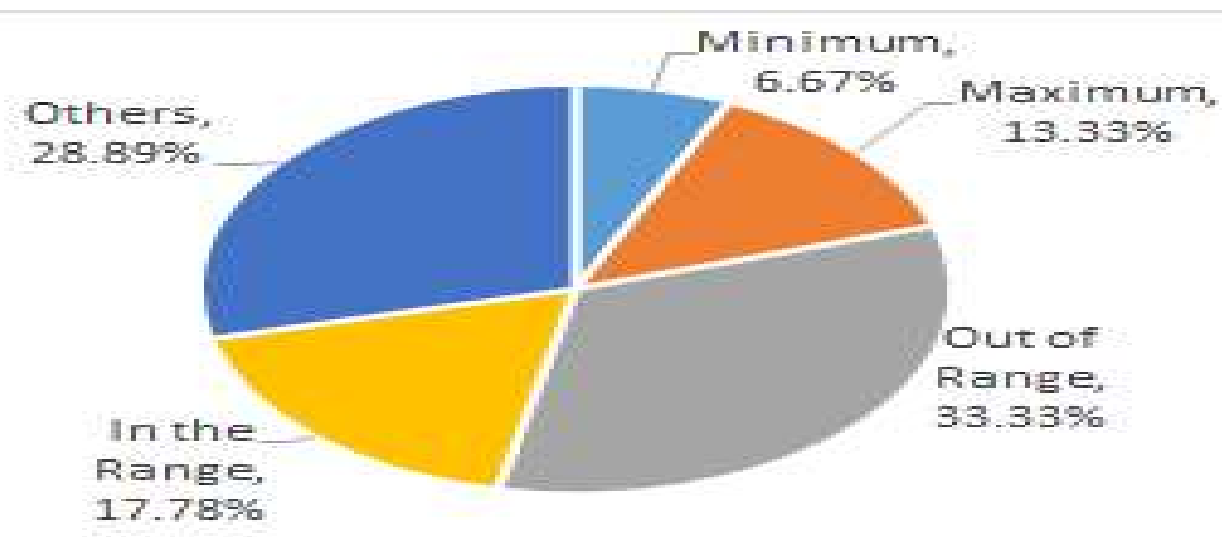

Fig.2. The amount of damages received by the respondent or plaintiff

\subsection{Evaluation Levels beyond the Range of the Highest Award}

A total of 15 cases were recorded as cases beyond the range of the amount of damages. The evaluation involves cases was assessed from 1990 to 2013, excluding cases in 1989. Therefore, 13 cases beyond of the range were taken into account. There are two criterions which that emphasized the case of exceeding the maximum range and the case that is less than the minimum range. It was found that 10 of the 13 cases registered are cases with a level less than the minimum range in the guidelines. There are three cases that have the amount of damages exceeding the maximum range in the guidelines and the two of them after the guideline amount of damages was introduced (operation of the scars and injury at the right eye).

The analysis of cases exceeding the maximum range clearly shows that there is a lack of decisions made by the court. This will affect the reputation of the judiciary and a number of parties including the insurance companies. Insurance companies play a role in motor policy claims for bodily injury to a third party. So, there is injustice and the losses incurred by the insurer in settling claims.

\subsection{Comparison Amount of Compensation for the Same Injury Cases}

There are two types of injuries and one claim identified for this analysis. Category of injuries 
involved were knee injury and metacarpals and a claim of prosthesis.

i. Knee Injury: There are two case laws of similar claims involving the knee injury:Chandra Sekaran A/L Krishnan Nair andAnor v AyubBin Mohamed andAnor [1994] MLJU (Malaysian Law Journal Unreported) 82 and Chang Ming Feng andAnor v Jackson Lim @ Jackson AkBajut [1999] MLJ (Malaysian Law Journal) 1. Refer to [14].

In both reported case laws, there was $22.22 \%$ increase in the amount of compensation injury within five years. The number increased every year using an annual effective rate formula is:

$$
\begin{aligned}
& \mathrm{RM} 11,000(1+i)^{-5}=\mathrm{RM} 9,000 \\
&(1+i)^{-5}=\frac{\mathrm{RM} 9,000}{\mathrm{RM} 11,000}=0.81818 \\
& i=\sqrt[5]{\frac{1}{0.81818}}-1 \\
& i=0.04095 \text { or } 4.1 \%
\end{aligned}
$$

Therefore, the amount of damages starting with RM9,000 in 1993 increased by $4.1 \%$ each year until getting RM11,000 in 1999.

ii. Metacarpus injury: Metacarpus injury also recorded in two case laws which has the same injury claims: Chandra Sekaran A/L Krishnan Nair and Anor v Ayub Bin Mohamed andAnor [1994] MLJU 82 and Abdul Aziz Bin AllaPichai v Fan Chin Siang @ Fun Kim Siong[1997] MLJU 123. Refer to [14].

Based on the cases, there was an increase by $50 \%$ the amount of damages for injuries metacarpus in the last three years. The annual effective rate:

$$
\begin{aligned}
\mathrm{RM} 5,000(1+i)^{-3} & =\mathrm{RM} 2,500 \\
(1+i)^{-3} & =\frac{\mathrm{RM} 2,500}{\mathrm{RM} 5,000}=0.5 \\
i & =\sqrt[3]{\frac{1}{0.5}}-1 \\
i & =0.25992 \text { or } 25.99 \%
\end{aligned}
$$

The results showed that the amount of damages starting with RM2,500 in 1994 has increased by almost 26\% per year so as to obtain RM5,000 in 1997. 


\subsection{The Comparison of Multiplier in Odgen Table with Prescribed for the Calculation of Compensation in Earnings}

i. General comparison: Table 2 consists of 11 level of ages that are taken randomly. The results indicated that the multiplier used in the calculation Odgen Table is more specific and systematic. Gender and age are significant variables in evaluation of multiplier because there is a difference between male and female values. In addition, different interest rates also affect the value of multiplier namely increasing interest rates, decreasing the multiplier. In overall, the multiplier of Odgen Table is higher than the statutory multiplier set out Section 28A Civil Law Act (Amendment) 1984.

ii. Comparison in the Court Cases Studied: An extension for the comparison in multiplier is to compare the data of case laws that have been studied to obtain compensation earnings using different multipliers. Table 2 shows the different multiplier will bring the different amount of compensation earnings. The Odgen table uses an interest rate of $4 \%$. Based on the cases studied, all cases have the multiplier higher than multiplier stated in Section 28A of the Civil Law Act (Amendment) 1984.

The study found that an increase in life expectancy also affects the age of a person. Thus, the age factor will affect the amount of compensation to be received as earn increases a person's age is decreasing their life expectancy and multiplier values. However, if the multiplier specified in Section 28A of the Civil Law Act (Amendment) 1984 indicates the plaintiff under the age of 30 years, multiplier with only 16 will be used. It can be concluded that there was flexibility within the defined multiplier and multiplier in Odgen table is more appropriate for the calculation of damages or loss.

According to Table 3, a total of 12 court cases complete listing of both types of compensation earnings, namely before and after the trial. There are seven plaintiffs who have an age range between 20 years to 25 years. They consist of five men and two women. In addition, the four plaintiffs are aged between 31 years to 40 years with three men and a woman.

Meanwhile, only one person aged 41 years and above that is a man. Overall, nine men and three women were recorded in the assessments and the majority of ages involved in this analysis are in their $20 \mathrm{~s}$. 
Table 2.General comparison of multiplier

\begin{tabular}{|c|c|c|c|c|c|c|c|}
\hline \multirow{3}{*}{ Ages } & \multicolumn{6}{|c|}{ Multiplier (Odgen Table) } & \multirow{3}{*}{$\begin{array}{c}\text { Multiplier } \\
\text { (Stated in } \\
\text { Section 1984) }\end{array}$} \\
\hline & \multicolumn{3}{|c|}{$\begin{array}{c}\text { Female } \\
\text { Interest Rates }\end{array}$} & \multicolumn{3}{|c|}{$\begin{array}{c}\text { Male } \\
\text { Interest Rates }\end{array}$} & \\
\hline & $2 \%$ & $3 \%$ & $4 \%$ & $2 \%$ & $3 \%$ & $4 \%$ & \\
\hline 18 & 26.01 & 22.32 & 19.39 & 25.68 & 22.06 & 19.18 & 16 \\
\hline 20 & 25.03 & 21.64 & 18.90 & 24.74 & 21.40 & 18.71 & 16 \\
\hline 22 & 24.02 & 20.91 & 18.38 & 23.76 & 20.70 & 18.20 & 16 \\
\hline 24 & 22.97 & 20.14 & 17.81 & 22.73 & 19.94 & 17.65 & 16 \\
\hline 26 & 21.87 & 19.32 & 17.19 & 21.66 & 19.14 & 17.05 & 16 \\
\hline 28 & 20.73 & 18.45 & 16.53 & 20.54 & 18.29 & 16.40 & 16 \\
\hline 30 & 19.54 & 17.53 & 15.81 & 19.38 & 17.38 & 15.69 & 16 \\
\hline 33 & 17.67 & 16.04 & 14.62 & 17.53 & 15.91 & 14.57 & 11 \\
\hline 35 & 16.37 & 14.97 & 13.75 & 16.23 & 14.85 & 13.65 & 10 \\
\hline 40 & 12.86 & 12.01 & 11.24 & 12.76 & 11.92 & 11.16 & 7.5 \\
\hline 45 & 9.00 & 8.59 & 8.21 & 8.93 & 8.52 & 8.14 & 5 \\
\hline
\end{tabular}

In addition, demographic factors play an important role in the analysis that takes into account gender and age in the calculation. Gender factor played a major role compared to the usual method stated in Section 28A of the Civil Law (Amendment) Act 1984. Women were found to have the multiplier higher than men. This is because a woman's life expectancy is higher than man. For example, the cases involving the plaintiff RubiahBteAnuar and Loo Kwai Fong. Both aged 21 years and came from different genders. The Table 3 shows the multiplier for RubiahBteAnuar is 18.64 , but Kwai Fong Loo 18.46 only. So, there is a significant gap between the values of the different genders.

The difference between the compensation earnings of both methods shows all the cases showed significant differences in the compensation Odgen multiplier in Table higher than a predetermined multiplier. The difference compensation highest earnings recorded is the plaintiff's case Chandra Sekaran A / L Krishnan, namely 51.42\%. 
Table 3. Comparison of compensation earnings in court cases studied

\begin{tabular}{|c|c|c|c|c|c|}
\hline \multirow[t]{2}{*}{ Cases } & \multicolumn{2}{|c|}{ Method 1} & \multicolumn{2}{|c|}{ Method 2} & \multirow[t]{2}{*}{ Difference } \\
\hline & $\begin{array}{c}\text { Multiplier } \\
\text { (Fixed) }\end{array}$ & $\begin{array}{l}\text { Loss of } \\
\text { Earnings }\end{array}$ & $\begin{array}{c}\text { Multiplier } \\
\text { (Odgen } \\
\text { Table) }\end{array}$ & $\begin{array}{c}\text { Loss of } \\
\text { Earnings }\end{array}$ & \\
\hline $\begin{array}{c}\text { N Vijaya Kumar } \\
\text { S/0 }\end{array}$ & 14 & RM96,000 & 17.35 & RM116,100 & $20.94 \%$ \\
\hline $\begin{array}{c}\text { Narayanasamy } \\
\qquad(\mathrm{M} / 25)\end{array}$ & & & & & \\
\hline $\begin{array}{l}\text { Shivanathan } \\
\text { (M/24) }\end{array}$ & 16 & RM24,360 & 17.65 & RM26,736 & $9.75 \%$ \\
\hline $\begin{array}{c}\text { Chuah Lay Boon } \\
\qquad(\mathrm{W} / 26)\end{array}$ & 16.67 & RM24,000 & 17.19 & RM24,628 & $2.62 \%$ \\
\hline $\begin{array}{c}\text { Chandra } \\
\text { Sekaran A/L } \\
\text { Krishnan } \\
\text { (M/41) }\end{array}$ & 7 & RM109,200 & 10.6 & RM165,360 & $51.42 \%$ \\
\hline $\begin{array}{l}\text { Lai See Yim } \\
\text { (M/38) }\end{array}$ & 8.5 & RM153,000 & 12.21 & RM219,780 & $43.65 \%$ \\
\hline $\begin{array}{l}\text { Appalasamy A/L } \\
\text { Bodoyah (M/31) }\end{array}$ & 12 & RM86,400 & 15.31 & RM110,232 & $27.58 \%$ \\
\hline $\begin{array}{c}\text { Anthony A/L } \\
\text { ArokyasamySee } \\
\text { mome }(\mathrm{M} / 27)\end{array}$ & 14.4 & RM62,250 & 16.73 & RM72,066 & $15.77 \%$ \\
\hline $\begin{array}{l}\text { Kamaruddin Bin } \\
\text { Ramli (M/27) }\end{array}$ & 16 & RM141,080 & 16.73 & RM147,299.6 & $4.41 \%$ \\
\hline $\begin{array}{c}\text { RubiahBteAnuar } \\
\qquad(\mathrm{W} / 21)\end{array}$ & 13 & RM62,400 & 18.64 & RM89,472 & $43.39 \%$ \\
\hline LooiKwai Fong & 16 & RM137,000 & 18.46 & RM166,920 & $21.84 \%$ \\
\hline
\end{tabular}


$(\mathrm{M} / 21)$

\begin{tabular}{cccccc}
$\begin{array}{c}\text { Yong Wah Sing } \\
(M / 33)\end{array}$ & 16 & RM336,200 & 14.51 & RM420,440 & $25.06 \%$ \\
$\begin{array}{c}\text { KhajijahBinti } \\
\text { Led and others } \\
(W / 35)\end{array}$ & 10 & RM149,531 & 13.75 & RM192,551 & $28.77 \%$ \\
\hline
\end{tabular}

$* \mathrm{M}=\mathrm{men}, \mathrm{W}=$ women

\section{CONCLUSION}

It is time look back to the evaluation of personal injury claims in Malaysia under the Civil Law (Amendment) Act 1984 given the inconsistency of the court decisions which may affect fairness to the disputing parties. Malaysian Bar-term fairness was an existing one to be used now. Foreign countries such as the United Kingdom and the United States have long used the multiplier in Odgen table for the calculation of damages or loss. Systematic assessment taking into account demographic factors greatly assist the court in making a decision that is fair to the victims.

This study can be extended to involve calculation of special damages such as expenses and claims the costs of plaintiff care. In addition, the study can also be expanded with regard to personal injury cases such as the effects of the use of cosmetic products, snatch theft and abuse.

\section{REFERENCES}

[1] DinaM.Malaysia has 17th most dangerous roads in the world, according to Michigan university research. Star Portal Online, 2014, http:/www.thestar.com.my/news/nation/2014/02/22/nations-with-deadliest-roads-malaysia-17 th/

[2] Azman A.Malaysia pegangrekodkematianjalanraya. UtusanMelayu Portal Online,2010,http://www.utusan.com.my/utusan/info.asp?y=2010\&dt=1008\&pub=Utusan_Ma laysia\&sec=Rencana\&pg=re_03.htm

[3] Haslifah H, Massita M.Factors in estimating compensation in personal injury and 
wrongful death using actuarial approach. In International Conference on Financial Management and Economics, 2011, pp. 334-337

[4] NathanR. K. Quantum of damages.Kuala Lumpur: Malayan Law Journal Pte Ltd.,1991

[5] David GJ D.Common kinds of personal injury cases a look at common kinds of personal injury cases, and what to expect.2014, http://www.alllaw.com/articles/nolo/personal-injury/kinds-of-cases.html

[6] CathyJ. O.Tort and personal injury law. Boston: Cengage Learning, 2013

[7] Butt Z, Haberman S, Verrall R, Wass V. Calculating compensation for loss of future earnings: Estimating and using work life expectancy. Journal of the Royal Statistical Society: Series A (Statistics in Society), 2008, 171(4):763-805

[8] LimH. S. Assessmentof damages in personal injury and fatal accident claims: Principles and practice. Kuala Lumpur: Marsden Law Book Sdn. Bhd., 1995

[9] Sumintha S K.Completion of the review of the compendium of personal injury award.2010,http://www.malaysianbar.org.my/task_force_to_review_the_compendium_of_ personal_in/completion_of_the_review_of_the_compendium_of_personal_injury_awards. html

[10]Balan P. Damages for personal injuries and causing death: A critical survey. Journal of Malaysia and Comparative Law,2004, 31(1):45-68

[11] Richard M. Getting to know the "Ogden Tables". Lamb Chambers.2013, http://www.lambchambers.co.uk/sites/default/files/event_downloads/getting-to-know-odg en-tables-richard-Menzies-2013.pdf

[12] Verrall R, Haberman S, Butt Z. An investigative study on current practice of estimating the loss of earnings in personal injury claims in England and Wales: The Ogden Tables and contingencies other than mortality. Working Paper; 2005, pp. 1-27

[13] Alistair N. Life contigencies. Oxford: Heinemann Professional Publishing Ltd., 1989

[14] LexisNexis ${ }^{\circledR}$ Malaysia Sdn. Bhd. Lexis legal research for academics portal. 2014, https://www.lexisnexis.com/my/legal/

Najihan A, Noriza M, Syadatul M,Junaida M.An Analysis on Compensation of Claims Regarding to Personal Injury and Loss of Earning on Several Court CasesJ. Fundam. Appl. Sci., 2017, 9(6S), 358-370. 